DOI: $10.1515 /$ pts-2016-0030

ELECTRONICS

\title{
INVESTIGATION ON MAXIMUM AVAILABLE REACH FOR DIFFERENT MODULATION FORMATS IN WDM-PON SYSTEMS
}

\author{
I. Kurbatska, V. Bobrovs, S. Spolitis, P. Gavars, G. Ivanovs, R. Parts \\ Institute of Telecommunications, Riga Technical University, \\ 12 Azenes Str., LV-1048, Riga, LATVIA \\ e-mail: inna.kurbatska@rtu.lv
}

\begin{abstract}
Considering the growing demand for broadband of access networks, in the present paper we investigate various modulation formats as a way of increasing the performance of optical transmission systems. Non-return-to-zero (NRZ) on-off keying, return-to-zero (RZ) OOK, carrier suppressed RZ (CSRZ) OOK, duobinary (DB), NRZ differential phase shift keying (NRZDPSK), RZDPSK and CSRZ-DPSK formats are compared using the maximal achievable reach with bit error rate less than $10^{-9}$ as a criterion. Simulations are performed by using OptSim software tool. It is shown that using the transmission system without dispersion compensation the best results are shown by duobinary and CSRZ-OOK modulation formats, but with the system using dispersion compensating fiber (DCF) the longest transmission distance is achieved by RZDPSK modulation format. By investigating the influence of channel spacing for best-performed modulation formats, network reach decrease for transmission systems with DCF fiber has been observed due to channel crosstalk.

Keywords: carrier suppressed RZ (CSRZ), chromatic dispersion (CD) compensation, dispersion compensating fiber (DCF), duobinary (DB), modulation formats, non-return-to-zero (NRZ), NRZ differential phase shift keying (NRZ DPSK), return-to-zero (RZ), wavelength division multiplexing (WDM).
\end{abstract}

\section{INTRODUCTION}

According to [1] there are three main components of Internet traffic - web data, file sharing, and internet video wherein the percentage of video traffic is growing annually. Different voice services, videoconferencing, telecommuting, distance learning, online e-commerce, always-on communication, the exchange of larger attachments for emails and messaging - all this increases the subscribers' demand for internet broadband [2], [3]. That is why copper technologies based on digital subscriber line (DSL), which have been widely used over the past 10 to 15 years, are not more able to satisfy these demands [4]. For this reason, new solutions should be found for access networks. 
Today one of them is widely applied FTTH technology. There are various Fiber to the X (FTTX) solutions, which differ for the different fiber termination points in the optical distribution network (ODN). The performance of Fiber to the Home (FTTH) networks is the best, but they are also the most expensive to implement [5]. FTTH or Fiber to the Building (FTTB) is the leading ultrafast broadband solution and its adoption in Europe is growing (the total number of subscribers increased by $29 \%$ in 2013). By the end of 2013, 34 global and 23 European countries had reached the threshold of more than $1 \%$ of homes directly connected with optical fiber. But only in the nine countries around the world FTTH/B subscribers are more than $20 \%$ of its households [6], [7]. This means that applying of FTTH is still topical.

Although there are several scenarios for FTTH implementation such as passive optical network (PON), active optical network (AON) and point-to-point (P2P) physical link from the central office $(\mathrm{CO})$ to each user, PONs are actually considered the most cost-effective way [5]. That is why PON performance improvement is the aim of our research. There are several PON standards. According to [8] GigabitCapable PON (GPON) is currently dominating in the world market, but 10 Gigabit Ethernet-PON (10G - EPON) and 10G-PON (XG-PON) are currently at beginning phase of mass-market adaptation. In 2015 global spending to PON technology was divided in the following way: GPON - $50 \%, 10 \mathrm{G}$ EPON - $22 \%$, EPON - $18 \%$, XG-PON - $12 \%$.This means that $10 \mathrm{Gbit} / \mathrm{s}$ systems are being widely enough introduced now and for this reason we are using this speed in our transmission system simulation. In the roadmap defined by the Full Service Access Network (FSAN) group, describing the evolution of optical access networks in the next years, XGPON has already been selected as the best candidate for next generation PON1 (NGPON1) solutions [5]. This is the first phase of NG-PON project. NG-PON1 considers the ODN-compatible systems, and NG-PON2 requires the ODN to be changed [4]. The technology, which can substitute traditionally used TWDM-PON in NG-PON2, is WDM-PON that we consider in the present paper. In WDM-PON signal splitting is carried out using optical wavelength division instead of previously used optical power division.

As mentioned above, the increase of transmission bandwidth is an important task to solve today. One of the ways how to increase the capacity and scalability of transmission system is by using appropriate modulation format [5], [9], [10]. There are three physical attributes that can be used to carry information: intensity, phase (including frequency), and polarization. Respectively, there are four modulation formats - amplitude shift keying (ASK) also known as on-off keying (OOK), phase shift keying (PSK), frequency shift keying (FSK) and polarization shift keying (PolSK). FSK is rarely used for lightwave systems due to complexity involved in recovering the frequency-coded information. Polarization shift keying (PolSK) has also received comparatively little attention for use in WDM-PON access networks due to its complexity [4], [9], [10]. There are also some advanced formats, which are combination of the above-mentioned modulation techniques, for example, quadrature amplitude modulation (QAM), which is the combination of ASK and PSK, where both the phase and amplitude of the carrier are changed at the same time [9].

According to [11] till lately, the dominant optical modulation format in the optical transmission system was non-return-to-zero (NRZ) on-off keying OOK with 
direct detection (DD); however, demand on higher data rates, better system reliability and optimal working conditions motivated many studies in this field.

In the present paper, we focus on modulation formats, which may show better performance in comparison with traditionally used NRZ-OOK and are not so difficult to implement as advanced modulation formats such as, for example, QAM or QPSK. For relatively not very high speed as $10 \mathrm{Gbit} / \mathrm{s}$, it is more profitable to use more cost effective solutions if they are able to fulfil the technical network needs. Hence, we compare the maximal reach of systems with NRZ-OOK, RZ-OOK, CSRZ-OOK, DB, NRZ-DPSK, RZ-DPSK and CSRZ-OOK formats. Authors in [12] compare the formats implemented in different network topologies with various splitting ratios and relatively small optical transmission length. The results show that among OOK formats (NRZ, RZ, CSRZ and CRZ) CSRZ and CRZ formats have the lowest BER. Comparing between NRZ, CSRZ and DB, the best performance is demonstrated by CSRZ, followed by DB and finally by NRZ. In comparison with NRZ-DPSK, RZDPSK show better performance. Authors in [11] compare NRZ, RZ, CRZ, CSRZ, DB, NRZ-DPSK and RZ-DPSK and the best performance is shown by DB and good results are also demonstrated by NRZ-DPSK. These results are obtained for 8-channel WDM-PON with transmission over $50 \mathrm{~km}$ long fiber span. We compare the performance of these formats (excluding CRZ and including CSRZ-DPSK) for 16 channel WDM-PON and longer distances, in addition investigating different channel spacing. Analogical approach is applied in [13], authors demonstrate that using DB format, the signal can be transmitted over $130 \mathrm{~km}$ long fiber span by using $25 \mathrm{GHz}$ channel spacing. NRZ-DPSK can be transmitted over $100 \mathrm{~km}$, but RZ-DPSK, CSRZ and NRZ over $70 \mathrm{~km}$. For RZ transmission distance is smaller. DB also showed good results using $12.5 \mathrm{GHz}$ channel spacing. We demonstrate that maximal reach can be even longer using DCF.

Extension of the maximum available reach or the number of end-users (which are conflicting requirements) of a single PON allows consolidating the number of COs and, respectively, the operators' expenses [5]. Hence, we evaluate the maximal transmission distance of system using each modulation format to compare their performance. To find out which modulation format is most appropriate for definite transmission conditions in WDM-PON system, we evaluate their performance with and without dispersion compensation module (DCM). One of the solutions how to increase transmission capacity or spectral efficiency is to reduce the channel spacing [14]. For this reason, different channel spacings are investigated in our WDM-PON research.

We use the OptSim software for our simulations. In OptSim software, signal propagation in the optical fiber transmission system is described solving the nonlinear Schrödinger equation using the Time Domain Split Step (TDSS) technique, which allows simulating linear and nonlinear effects independently of each other [15].

\section{SIMULATION MODEL OF WDM-PON TRANSMISSION SYSTEM WITH DIFFERENT MODULATION FORMATS}

Our implemented simulation scheme of WDM-PON optical access system is shown in Fig. 1. As typical PON, it consists of three main parts: optical line terminal 
(OLT), optical distribution network (ODN) and optical network terminal (ONT). OLT is located at operator's central office $(\mathrm{CO})$ and ensures data exchange among the PON and metro-access or long haul network. ODN performs the transport function and, consequently, includes an optical transmission line. Besides, optical splitters and optical combiners, which are situated at $\mathrm{CO}$ and remote node (RN) are also part of ODN. What is important, according to PON principles, all optical equipment placed in ODN should be passive. ONT is situated at user's side and its function is to convert received optical signal to electrical and contrariwise [16].

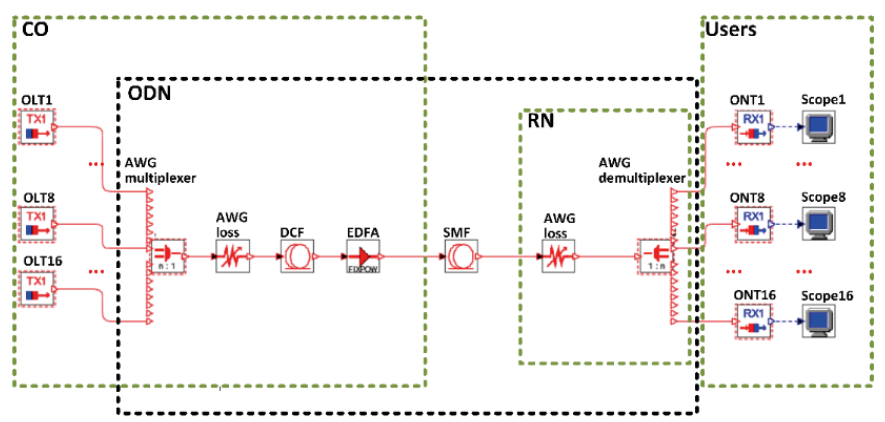

Fig. 1. Simulation scheme of 16-channel WDM-PON transmission system with transmission speed of $10 \mathrm{Gbit} / \mathrm{s}$ per channel.

Our WDM-PON system consists of $1610 \mathrm{Gbit} / \mathrm{s}$ channels with $193.1 \mathrm{THz}$ central frequency. The initial channel spacing is $100 \mathrm{GHz}$ and channel frequencies are assigned according to ITU-T G.694.1 recommendation. This recommendation defines the DWDM frequency grid, i.e., the values of central frequencies for the transmission channels [17].

Our simulation model is one-directional and executes data transmission from an operator to a user (download). For this reason, as one can see in Fig. 1, optical transmitter forms OLT and is situated at CO, but ONT is composed of an optical receiver. Each modulation format requires different transmitter structure, but in our simulations all of them are based on $\mathrm{CW}$ laser with $+2 \mathrm{dBm}$ output power and 50 $\mathrm{MHz} 3-\mathrm{dB}$ linewidth. Transmitter schemes, which have been used in our case, are shown in Fig. 2 and will be described further. Receivers for all intensity modulation formats and for all phase modulation formats are similar. Receiver for intensity modulated signals is based on PIN photodetector with $-22 \mathrm{dBm}$ sensitivity [5], [18]. Receiver, which is used for phase modulated signals, consists of tunable MachZehnder interferometer where optical paths differ by a delay equal to the duration of bit and two PIN photodetectors with responsivity of $0.75 \mathrm{~A} / \mathrm{W}$ at reference frequency of $1550 \mathrm{~nm}$ and $2 \mathrm{nA}$ dark current. Each optical output of interferometer is detected by PIN photodetector. The output electrical signal is the difference between the PIN detected currents [18], [19]. Electrical signals on the output of receivers are filtered using low-pass Bessel electrical filter with bandwidth experimentally chosen as the most appropriate for each modulation type.

In our simulation model, we use arrayed waveguide grating (AWG) based multiplexer for channel combining. For dispersion compensation, dispersion compensation fiber (DCF) is used [20]. AWG together with DCF and erbium-doped fi- 
ber amplifier (EDFA) is placed at CO. DCF is used only in the second simulation scenario, for the research of WDM-PON systems without dispersion compensation. EDFA used in our simulations has fixed output power equal to $+16 \mathrm{dBm}$. The key parameters of DCF fiber are attenuation coefficient $\alpha=0.6 \mathrm{~dB} / \mathrm{km}$, dispersion coefficient $D=-80 \mathrm{ps} /(\mathrm{nm} \cdot \mathrm{km})$ and dispersion slope $D_{s l}=0.19 \mathrm{ps} /(\mathrm{nm} 2 \cdot \mathrm{km})$. The standard ITU-T G.652 single mode fiber (SMF) is used as the optical transmission line. AWG demultiplexer, which is situated at remote node $(\mathrm{RN})$, is used for signal splitting and filtering. The insertion loss of both AWG multiplexers and demultiplexers is equal to $3 \mathrm{~dB}$ and is simulated by using additional optical attenuators.
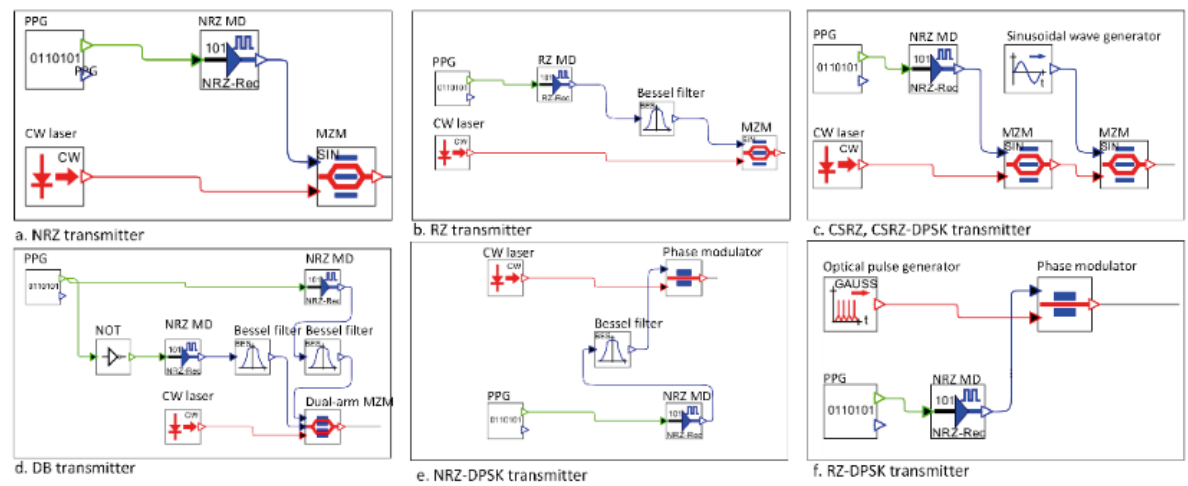

Fig. 2. Different type optical transmitters for implementation of the following modulation formats:

(a) NRZ, (b) RZ, (c) CSRZ and CSRZ-DPSK, (d) DB, (e) NRZ-DPSK, and (f) RZ-DPSK.

As mentioned above, transmitters for all our investigated modulation formats are shown in Fig. 2. NRZ transmitter is shown in Fig. 2(a). It is built according to a typical NRZ transmitter structure based on MZM. Electrical signal for MZM is provided by NRZ modulator driver (MD), which forms NRZ line code according to pseudo random bit sequence from pulse pattern generator (PPG) at $10 \mathrm{Gbit} / \mathrm{s}$ bit rate. Analogically formed RZ transmitter is shown in Fig. 2(b). It is implemented by electronically generating RZ pulses and, consequently, differs from the previous transmitter only by the way, how an optical modulator is driven. There is also the Bessel filter used for signal from modulator driver filtering. The structure of CSRZ-OOK and CSRZ-DPSK transmitter is shown in Fig. 2(c). The transmitters of these formats have a similar structure although element parameters are different. The modulation of optical signal is carried out in two stages. In the first stage, MZM is used for phase or intensity modulation. Then the second stage applies an alternate-phase pulse carving to the signal. It is composed by MZM modulator driven by a sinusoidal signal with frequency equal to half of the bit rate [18]. The duobinary transmitter can be seen in Fig. 2(d). The dual-arm MZM is driven with two inverse NRZ signals prefiltered using a low-pass Bessel filter. For NRZ-DPSK and RZ-DPSK modulation the transmitters are based on phase modulator (PM) from OptSim models library. They are shown in Fig. 2(e) and Fig. 2(f) and have a similar structure. The difference is that they are accordingly driven by NRZ and RZ modulator drivers and for RZDPSK transmitter Super-Gaussian optical pulse generator (based on CW laser with the same parameters) is used as an optical signal source. 


\section{RESULTS AND DISCUSSION}

As the main criterion for performance comparison of investigated modulation formats we have chosen the maximal transmission distance, which can be achieved under the defined signal quality. As threshold for maximal distance evaluation the BER less than $10^{-9}$ in each channel has been chosen. At first we evaluated performance of all modulation formats (NRZ-OOK, RZ-OOK, CSRZ-OOK, NRZ-DPSK, RZ-DPSK, CSRZ-DPSK and DB) in system without dispersion compensation. Maximal transmission distances obtained by each format are shown in Table 1. As one can see, the best performance is demonstrated by DB and CSRZ-DPSK - their maximal distance is more than $90 \mathrm{~km}$. Results of NRZ-OOK, both OOK and DPSK are also quite good - the maximal reach is above $80 \mathrm{~km}$.

Table 1

Maximal Transmission Distance of Modulation Formats in System without DCM

\begin{tabular}{|l|c|c|}
\hline No. & Format & Distance $(\mathrm{km})$ \\
\hline 1. & DB & 99 \\
\hline 2. & CSRZ-DPSK & 92 \\
\hline 3. & NRZ-OOK & 82 \\
\hline 4. & NRZ-DPSK & 80 \\
\hline 5. & CSRZ-OOK & 72 \\
\hline 6. & RZ-OOK & 60 \\
\hline 7. & RZ-DPSK & 54 \\
\hline
\end{tabular}

Table 2 demonstrates the performance of each modulation format in the system where DCF is used. As it is shown in Table 2, in the system with DCF the performance of DPSK formats is much better than performance of OOK formats. To analyse the influence of dispersion on each format performance, data about an increase of maximal reach of each format using the dispersion compensation are also summarised in Table 2. Distance increase is evaluated in relation to maximal reach without DCF. As one can see, chromatic dispersion is the main distance-limiting factor for RZ-DPSK format. For DB, on the contrary, dispersion compensation has not improved reach significantly.

Table 2

Maximal Transmission Distance of Modulation Formats in System with DCF

\begin{tabular}{|c|c|c|c|c|}
\hline No. & Format & $\begin{array}{l}\text { Distance } \\
(\mathrm{km})\end{array}$ & $\begin{array}{l}\text { DCF length } \\
(\mathrm{km})\end{array}$ & $\begin{array}{c}\text { Distance increase using } \\
\text { DCF }(\%)\end{array}$ \\
\hline 1. & RZ-DPSK & 203 & 38 & $276 \%$ \\
\hline 2. & NRZ-DPSK & 187 & 37 & $134 \%$ \\
\hline 3. & CSRZ-DPSK & 166 & 31 & $103 \%$ \\
\hline 4. & $\mathrm{RZ}$ & 122 & 22 & $80 \%$ \\
\hline 5. & NRZ & 115 & 20 & $51 \%$ \\
\hline 6. & CSRZ & 109 & 19 & $40 \%$ \\
\hline 7. & DB & 103 & 7 & $4 \%$ \\
\hline
\end{tabular}


The input spectra of all investigated modulation formats as well as input and output eye diagrams for both scenarios of transmission system are shown in Fig. 3.

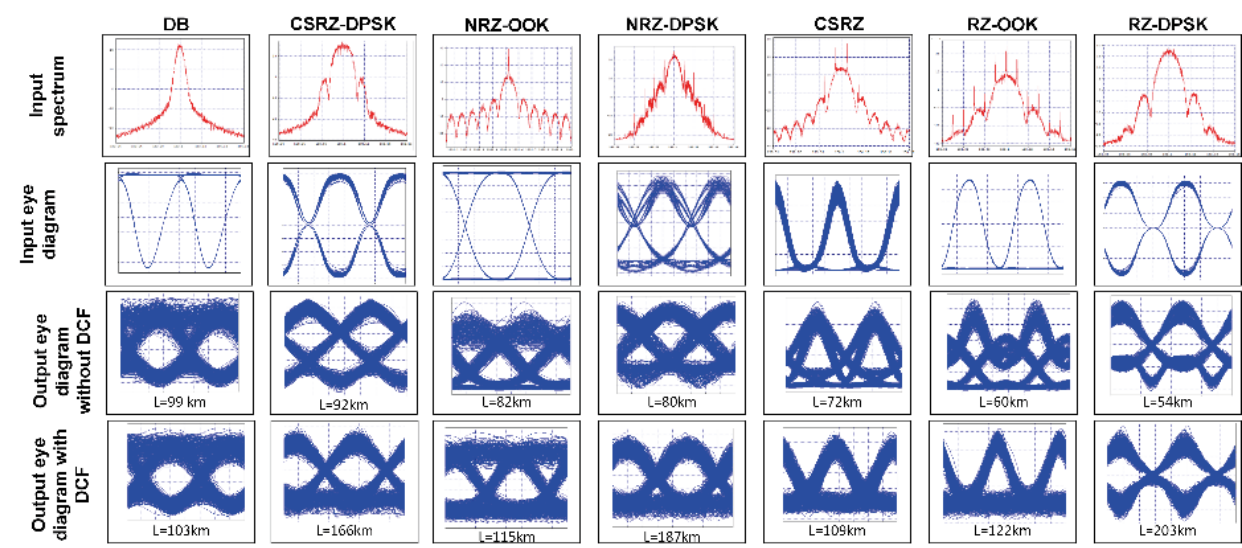

Fig. 3. Input spectra, eye diagrams and output eye diagrams at maximum achievable transmission distance in the systems without and with DCF dispersion compensation module.

In addition, the performance of three best performed modulation formats in both scenarios was evaluated by changing channel spacings. According to ITU-T G.694.1 recommendation, $25 \mathrm{GHz}$ and $50 \mathrm{GHz}$ spacings were investigated. The results are shown in Table 3.

Table 3

Maximal Transmission Distance of Modulation Formats in Systems without and with DCF Using $100 \mathrm{GHz}, 50 \mathrm{GHz}$ and $25 \mathrm{GHz}$ Channel Spacings

\begin{tabular}{|c|c|c|c|c|}
\hline No. & Format & $\begin{array}{c}\text { Distance }(\mathrm{km}) \\
\text { Channel spacing: } 100 \\
\text { GHz }\end{array}$ & $\begin{array}{c}\text { Distance }(\mathrm{km}) \\
\text { Channel spacing: } \\
50 \mathrm{GHz}\end{array}$ & $\begin{array}{c}\text { Distance }(\mathrm{km}) \\
\text { Channel spacing: } 25 \\
\mathrm{GHz}\end{array}$ \\
\hline \multicolumn{5}{|c|}{ System without DCF } \\
\hline 1. & DB & 99 & 101 & 105 \\
\hline 2. & CSRZ-DPSK & 92 & 91 & 93 \\
\hline 3. & NRZ-OOK & 82 & 84 & 77 \\
\hline \multicolumn{5}{|c|}{ System with DCF } \\
\hline 1. & RZ-DPSK & 203 & 190 & 162 \\
\hline 2. & NRZ-DPSK & 187 & 172 & 151 \\
\hline 3. & CSRZ-DPSK & 166 & 159 & 154 \\
\hline
\end{tabular}

As one can see, transmission with $50 \mathrm{GHz}$ and $25 \mathrm{GHz}$ channel spacings in the system without dispersion compensation and, consequently, with smaller transmission distances has been implemented as successfully as with $100 \mathrm{GHz}$ channel spacing; in some case it has shown even better results. The reason of it can be that in our case nonlinear optical effects between channels have not increased BER value, but, on the contrary, improved it. Small decrease of reach was observed in NRZOOK system with $25 \mathrm{GHz}$ channel spacing. The decrease of transmission distance 
is more significant in the system with DCF. Especially it is substantial in the NRZDPSK case. Results demonstrated by NRZ-DPSK using $100 \mathrm{GHz}$ spacing were the best ones. However, the third best result is achieved when $25 \mathrm{GHz}$ spacing is used.

\section{CONCLUSIONS}

The recommendations and conclusions for the next generation of WDM transmission systems are as follows.

1. The maximal reach of 16-channel WDM-PON system without dispersion compensation module (DCM) was obtained by DB and CSRZ-DPSK formats; it was more than $90 \mathrm{~km}$ in comparison with more than $80 \mathrm{~km}$ achieved by NRZ-OOK. This means that in the systems where demand on maximal transmission distance is not very high, the usage of traditional NRZ-OOK remains a good cost-effective and simple solution. If it is necessary to achieve maximal reach without using dispersion compensation, the DB and CSRZ-DPSK are potentially the most suitable formats.

2. The decrease of the channel spacing to $25 \mathrm{GHz}$ has not affected maximal achievable reach in the simulated transmission systems without DCF; this means that it is possible to increase capacity as well as spectral efficiency in such kind of systems keeping maximal transmission length.

3. RZ-DPSK demonstrated the maximal achievable reach of the system (203 $\mathrm{km}$ ) using DCF and $100 \mathrm{GHz}$ channel spacing.

4. Significant increase of maximal achievable reach in 16-channel WDMPON system with DCF has shown that chromatic dispersion is an important limiting factor of system performance.

5. However, influence of chromatic dispersion on various modulation formats is very different. It is definitely the main limiting factor for RZDPSK, but for DB, on the contrary, chromatic dispersion is not the main or single limiting factor.

6. If DCF is applied, the use of another modulation format (especially DPSK format) instead of NRZ-OOK can significantly increase the maximal reach of system.

7. In the system with DCF, a decrease of channel interval is appreciable. The smaller the channel spacing, the shorter the maximal reach. In comparison with $203 \mathrm{~km}$ achieved by RZ-DPSK using $100 \mathrm{GHz}$ spacing, 50 $\mathrm{GHz}$ spacing enables transmission over slightly more than $190 \mathrm{~km}$ (RZDPSK), but using $25 \mathrm{GHz}$ interval only over approximately $150 \mathrm{~km}$.

\section{ACKNOWLEDGEMENTS}

The present research has been supported by the Latvian National Research Programme SOPHIS under grant agreement No. 10-4/VPP-4/11. 


\section{REFERENCES}

1. Cisco. (2014). Transformation through innovation: A strategy for service provider success. Executive Summary. Available at http://www.cisco.com/c/en/us/solutions/collateral/service-provider/service-provider-strategy/white_paper_c11-690395.html

2. Saunders, J. D., McClure, C. R., and Mandel, L. H. (2012). Broadband applications: Categories, requirements, and future frameworks. First Monday 17 (11).

3. ITU. (2011). Applications over broadband Internet. Available at https://www.itu.int/osg/ spu/spunews/2003/oct-dec/applications.html

4. Kaminow, I. P., Li, T., and Willner, A. E. (2013). Optical fiber telecommunications. Volume VIB: Systems and Networks. Academic Press.

5. Muciaccia, T., Gargano, F., and Passaro, V. M. N. (2014). Review Passive Optical Access Networks: State of the Art and Future Evolution. Photonics 4, 323-346. doi:10.3390/ photonics 1040323

6. IDATE Research. (2014). FTTx 2014 markets \& trends. Facts \& Figures.

7. FTTH. (2014). Press release. Fibre broadband flourishes as Switzerland joins the league of FTTH leaders.

8. Jansons, G. (2015). What is GPON? - Short Recap. Available at http://www.edgetech. lv/what-is-gpon/

9. Binh, L. N. (2015). Advanced digital optical communications. Second edition. Munich: CRC Press.

10. Winzer, J., and Essiambre, R. (2006). Advanced optical modulation formats. Proceedings of the IEEE 94 (5), 952-985.

11. Latal, J., Vitasek, J., Koudelka, P., Siska, P., Poboril, R., Hajek, L., Vanderka. A., and Vasinek, V. (2014). Simulation of modulation formats for optical access network based on WDM-PON. 16th International Conference in Transparent Optical Networks (ICTON), 1-7, 6-10.

12. Agalliu, R., and Lucki, M. (2014). Benefits and limits of modulation formats for optical communications. Optics and Optoelectronics 12 (2), 160-167.

13. Agalliu, R., and Lucki, M. (2015). System improvements in dense wavelength division multiplexing networks by using advanced optical modulation formats. 17th International Conference on Transparent Optical Networks (ICTON), 1-9. doi: 10.1109/ ICTON.2015.7193511

14. Ozolins, O., Bobrovs, V., and Ivanovs, G. (2012). DWDM-direct access system based on the fiber Bragg grating technology. Proceedings of the 8th International Symposium on Communication Systems, Networks and Digital Signal Processing, CSNDSP 2012, art. no. 6292669.

15. Udalcovs, A., Bobrovs, V., Trifonovs, I., and Celmins, T. (2013). Investigation of maximum distance reach for spectrally efficient WDM system with mixed data rates and signal formats. Elektronika ir Elektrotechnika, 19 (1), 87-92.

16. Spolitis, S., Bobrovs, V., Ivanovs, G., and Gavars, P. (2012). Comparison of passive chromatic dispersion compensation techniques for long reach dense WDM-PON system. Elektronika ir elektrotechnika 6 (122), 65-70.

17. Udalcovs, A., and Bobrovs, V. (2012). Investigation of spectrally efficient transmission for unequally channel spaced WDM systems with mixed data rates and signal formats. Proceedings of the 8th International Symposium on Communication Systems, Networks and Digital Signal Processing, CSNDSP 2012, art. no. 6292662.

18. OptSim User Guide. (2010). USA: RSoft Design Group. 
19. OSI Optoelectronics. FCI-InGaAs-36C 10Gbps InGaAs Photodiode. World Class Products - Light Sensing Solutions. Available at http://www.osioptoelectronics.com/application-notes/OSI_Parts_Catalog.pdf

20. Udalcovs, A., Bobrovs, V., Parts, R., and Trifonovs, I. (2012). Evaluation of the maximum permissible transmission distance for the mixed-HDWDM systems. Proceedings of the 9th International Symposium on Telecommunications, BIHTEL 2012, art. no. 6412052 .

\section{DAŽĀDU MODULĀCIJAS FORMĀTU MAKSIMĀLI SASNIEDZAMA PĀRRAIDES ATTĀLUMA IZPĒTE WDM-PON SISTĒMĀS}

I. Kurbatska, V. Bobrovs, S. Spolitis, P. Gavars, G. Ivanovs, R. Parts

Kopsavilkums

Ievērojot platjoslas pakalpojumu pieprasījuma apjoma pieaugumu piekḷuves tīklos, šajā pētījumā, tika novērtēta modulācijas formātu spēja palielināt pārraides sistēmas maksimālo attālumu ar signāla kḷūdas varbūtību ne augstāku par $10^{-9}$. Realizējot 16 kanālu viḷngarumdales blīvētu pasīvā optiskā tīkla pārraides (WDMPON) sistēmu, tika izpētīti tādi modulācijas formāti kā kodēšana bez atgriešanās pie nulles (non-return-to-zero (NRZ)), atgriešanas pie nulles (return-to zero (RZ)), RZ ar nesējfrekvences apspiešanu (carrier suppressed (CSRZ)), duo-binārā kodēšana (duobinary (DB)), NRZ ar diferenciālo fāzes modulāciju (NRZ differential phase shift keying (NRZ-DPSK), RZ-DPSK un CSRZ-DPSK. Simulācijas tika veiktas izmantojot OptSim programmu. Sistēmā bez dispersijas kompensāciju ar $100 \mathrm{GHz}$ starpkanālu intervālu labākus rezultātus demonstrēja DB un CSRZ-DPSK formāti, to maksimālais pārraides attālums ir vismaz $90 \mathrm{~km}$. NRZ-OOK maksimālais pārraides attālums ir virs $80 \mathrm{~km}$. Starpkanālu intervāla nomaiṇa no $50 \mathrm{GHz}$ uz $25 \mathrm{GHz}$ izmainīja maksimālo pārraides attālumu nebūtiski. Attiecībā uz pārraides sistēmu bez dispersijas kompensācijas var secināt, ka visperspektīvākie ir DB un CSRZDPSK formāti, bet atškikīība no tradicionāli izmantojamā NRZ-OOK nav pārāk lielā, tāpēc tas joprojām ir vienkāršs un ekonomisks risinājums, kad netiek izvirzîtas augstas prasības attiecība uz nodrošināmo pārraides attālumu. Sistēmā ar dispersiju kompensējošo šķiedru (DCF) maksimālais pārraides attālums ir daudz lielāks - 203 km (RZ-DPSK formāts), kas liecina par to, ka dispersija būtiski ietekmē pārraides sistēmas veiktspēju. Tomēr ne visiem formātiem dispersijas kompensācija ir izšķiroša. Piemēram, DB formātam maksimālais pārraides attālums palielinājās tikai par 4\%, salīdzinot ar 276\% RZ-DPSK gadījumā. Pārraides sistēmā ar DCF dispersijas kompensācijas moduli starpkanālu intervāla samazināšana jau būtiski ietekmē maksimālo pārraides attālumu. Ja starpkanālu intervāls ir $50 \mathrm{GHz}$, tad nodrošināmais pārraides attālums ar BER $<10^{-9}$ ir virs $190 \mathrm{~km}$ (RZ-DPSK formātam), bet ja intervāls tiek izraudzīts $25 \mathrm{GHz}$, tad maksimālais nodrošināmais attālums pārsniedz $150 \mathrm{~km}$. Ja tiek pielietota dispersijas kompensācija (DCF šķiedra), tad šajā gadījumā DPSK formātu izmantošana tradicionāla NRZ-OOK vietā var manāmi uzlabot pārraides sistēmas darbību.

30.03.2016. 